\title{
Vejledernes reaktion på retningslinjer for vejledning
}

\author{
Hanne Leth Andersen, professor, leder af Center for Undervisningsudvikling ved Humaniora \\ og Teologi, Aarhus Universitet og Tine Wirenfeldt Jensen, amanuensis på Center for \\ Undervisningsudvikling ved Humaniora og Teologi, Aarhus Universitet.
}
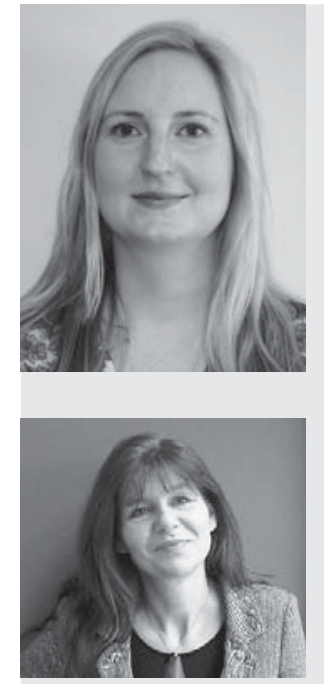

Tine Wirenfeldt Jensen er cand. mag. i litteraturhistorie og informationsvidenskab. Hun arbejder med akademiske skrive- og arbejdsprocesser i forbindelse med tværfaglige kursusforløb, sparring af fastkørte specialestuderende og i udviklingen af Studiemetroen (www.studiemetro.au.dk).

Hanne Leth Andersen er forsker inden for det universitetspædagogiske område med fokus på dialog, vejledning, evaluering, progression, kompetence- og vidensformer.Ansvarlig for kvalitetssikring og -udvikling og deltager i uddannelsespolitisk arbejde og ledelsesudvikling i forhold til det moderne universitet.

\section{Reviewet artikel}

Den undersegelse vi her $i$ artiklen rapporterer fra, viser at der blandt specialevejledere og specialestuderende er stor forskel på kendskabet til og interessen for de opstillede rammer og regler for specialevejledningen. Vi konstaterer at vejlederen ikke primert opfatter sig selv som en medarbejder i en organisation hvor ledelsens eventuelle retningslinjer og rammer er relevante og bindende, men snarere som en privatpraktiserende vejleder der udvikler sit eget tilbud til de studerende. Vejlederne har skullet udvikle deres egen praksis, men det er alligevel påfaldende at så få problematiserer deres manglende viden om institutionens retningslinjer. Nogle af vejledernes begrundelser for ikke at interessere sig mere for fagets retningslinjer afspejler en opfattelse af de geldende retningslinjer for deres praksis som irrelevante for dem. Baggrunden er at reglerne primart er kvantitative og rammescttende og slet ikke kommer $i$ dialog med vejledernes individuelle praksis. Hvis man vil udvikle vejledningspraksis, skal der altså andre mere kvalitative og peedagogisk velfunderede midler til.

\section{Undersøgelsens baggrund}

Der gøres i disse år meget for at kvalitetssikre specialevejledningen. Dette kan dels gøres ved at skabe klare retningslinjer for vejledning, primært med henblik på at give de studerende et velfungerende og nogenlunde ensartet vejledningstilbud, dels ved at diskutere hvordan man vejleder i substansen, fx med henblik på vægtningen af faglig vejledning og procesvejledning eller hvilke roller en vejleder indtager i forbindelse med denne undervisningsform. Der organiseres vejlederkurser og specialeworkshops, der udarbejdes specialekontrakter, og mange studieledere og studievejledere tager initiativ til specialeseminarer, skriveworkshops og pjecer med faste retningslinjer for vejledningen (Andersen, Hanne Leth og Jensen, Tine W., Specialevejledning - rammer og roller, under udg., Rienecker, Lotte; Harboe, Thomas og Jørgensen, Peter Stray, Vejledning - en brugsbog for opgave- og specialevejledere på videregående uddannelser, 2005.). Den kvantitative del skal sikre de studerende lige vilkår og handler om retningslinjer $\mathrm{i}$ forhold til timetal, procedure eller antal læste sider af det færdige speciale i forbindelse med vejledningen. Det drejer sig i denne forbindelse primært om at styrke de studerendes retssikkerhed i forhold til det vejledningsprodukt de făr tilbudt, og om at sikre gennemførsel, herunder normeret gennemførselstid. Men det er samtidig en del af tidens politiske trend at der fokuseres på ledelse af medarbejderne, målstyring og kvalitetssikring.Vi finder det relevant at undersøge vilkårene for kvalitetsudvikling ved at komme bag om vejledernes holdning til disse ledelsesmæssige tiltag.

\section{Metode}

I denne artikel præsenteres en mindre del af en større undersøgelse (Andersen og Jensen, under udg.). I undersøgelsen har vi udvalgt syv fag fra Det Humanistiske og Det Teologiske Fakultet på Aarhus Universitet og interviewet studielederne samt tre vejledere og tre 
studerende pr. fag, i alt 49 personer, i perioden juni 2005 til januar $2006^{1}$. Alle deltagere er anonyme. Udvælgelsen af fagene skete således at de er fordelt på syv forskellige institutter, og her lod vi i nogle tilfælde studielederen udpege de tre vejledere, mens vi i andre tilfælde selv udvalgte vejlederne. Flere steder er vejlederne valgt ud fra deres faglige område således at forskellige dele af fagene er representeret, men vi har ikke bedt om at fă de bedste vejledere. Undersøgelsen handler om praksis, men ikke nødvendigvis om best practice $^{2}$, og deltagerne er ikke metodisk udvalgt med sigte på at skabe en vejledningsmæssig repræsentativitet vi ikke på forhånd ville kunne etablere. Globalt set har vejlederne dog forskellige erfaringer med vejledning, og vi har sikret at der i undersøgelsen indgår både meget erfarne og nyere vejledere, vejledere placeret forskelligt i stillingsstrukturen og vejledere af begge ${\mathrm{k} ø \mathrm{n}^{3}}^{3}$. De studerende er bl.a. fundet via kontakt til fagene, studievejledere og opslag. Undersøgelsen sigter ikke mod at undersøge konkrete specialeforløb, hvorfor studerende og vejledere er valgt helt uafhængigt af hinanden. Interviewene blev gennemfort ud fra en spørgeguide og optaget på diktafon. Alle vejlederinterviews er fuldt transskriberede.

Undersøgelsen som helhed er kvalitativt anlagt og sigter på at indsamle viden og erfaringer om vejledning som den faktisk praktiseres på universitetet i dag. Dette felt er i dansk sammenhæng relativt uudforsket, og der findes ikke megen reel viden om hvad der foregår i vejledningen, men mange gode råd (jf. Harboe 2005, s.5).

I denne artikel fokuserer vi på en mindre del af undersøgelsen, nemlig på vejledernes kendskab til fagets formelle retningslinjer. Vi har i den forbindelse stillet følgende konkrete spørgsmål:

- Har I fælles retningslinjer for specialevejledningen?

- Har I fælles retningslinjer for hvor mange timer/ gange der vejledes?

- Har I fælles retningslinjer for hvor mange sider der læses, i procent?

Det første spørgsmål handler generelt om hvorvidt der findes fælles retningslinjer for specialet, uden at der lægges op til hvilken type af retningslinjer det kan være. Det kan altså både dreje sig om studievejledninger, specialepjecer, regler for valg af vejleder, vejlederskift eller eventuelle beslutninger om hvordan vejledningen skal gennemføres. Det er således et kvalitativt spørgsmål, men samtidig kan det være interessant at følge besvarelsen fra studieleder over vejleder til studerende og se hvorvidt eventuelle fælles retningslinjer fra studienævnets side i denne mere overordnede sammenhæn er kendt af de to parter i den konkrete vejledning. De to følgende spørgsmål handler udelukkende om kvantificerbare tiltag, nemlig timenormen for vejledning og en norm for vejledernes læsning af dele af specialet inden aflevering.
For alle tre spørgsmåls vedkommende er der i modsætning til resten af undersøgelsen tale om spørgsmål hvor der eksisterer rigtige og forkerte svar. De "rigtige « svar er givet af studielederne på de enkelte fag. De ved om der er fælles retningslinjer for indholdet af vejledning, de kender timenormen, og de ved om der er taget beslutning om at alle vejlederne læser cirka samme andel af hvert enkelt speciale. I alle tre tilfælde er det altså muligt at udlede hvor mange vejledere $i$ undersøgelsen der kender til og kan gengive deres fags formelle retningslinjer.

Vi har valgt at koble de kvantitative resultater vi kommer frem til i undersøgelsen, med vejledernes kvalitative udsagn om hvordan de forholder sig til retningslinjerne og til deres eventuelle mangelfulde kendskab til disse. Er det vigtigt at kende til retningslinjerne, og hvad betyder disse for den enkelte vejleder? Til dette formål har vi udvalgt repræsentative enkeltudsagn i forhold til de forskellige mulige positioner. Herved synliggøres og forklares vejledernes positioner i forhold til de nye krav til kvalitetssikring og kvalitetsudvikling på området. Med indsigt i disse positioner mener vi at få et bedre udgangspunkt for reelt at påvirke vejledningsarbejdet.

\section{Manglende kendskab til retningslinjer for vejledning}

Når der udvikles nye tiltag, retningslinjer og politikker inden for organisationer, er det et generelt problem at få disse til at nå ud til alle medarbejdere. Anette Grønning (Grønning, Anette: Personen bag. Tilstedevaer $i$ e-mail som interaktionsform mellem kunde og medarbejder $i$ dansk forsikringskontekst. København: Samfundslitteratur. 2006.) har i sin ph.d.-afhandling undersøgt e-mail-kommunikation mellem medarbejdere og kunder i et større forsikringsselskab, og hun kan konstatere at $32 \%$ af medarbejderne ikke kender organisationens e-mail-politik, at $19 \%$ aldrig læser e-mail-politikken (selv om de godt kender den) og endelig at $12 \%$ svarer "ved ikke" på spørgsmålet. Alt i alt kan man altså argumentere for at hele $63 \%$ af medarbejderne ikke kender eller har taget e-mail-politikken til sig. I samme organisation oplever $53 \%$ af medarbejderne at de ikke føler sig godt rustet til at skrive e-mails til organisationens kunder.

Vores undersøgelse kan bidrage med en parallel konklusion når det gælder viden om den vedtagne politik på specialevejledningsområdet. Mange vejledere er ikke bevidste om de helt overordnede rammer for specialevejledning som deres studienævn har vedtaget. Selv om vi altså kan konstatere en parallelitet med andre typer af organisationer, mener vi at der er delvist forskellige forklaringsmekanismer på spil i de forskellige typer af organisationer og arbejdssituationer. Den kvantitative analyse viser en fælles tendens, mens de kvalitative udsagn udpeger årsager der er specifikke for universitetets praksis på vejledningsområdet. 
Vi ser i det følgende nærmere på de mere håndfaste resultater af vores undersøgelse, nemlig svarene på de konkrete spørgsmål til vejledernes viden om 1) de fælles retningslinjer generelt, 2) tidsmæssige normer for vejledning, 3) antal læste sider af specialet inden aflevering.Vi kan på de tre områder udlede om de adspurgte vejledere kender eller ikke kender retningslinjerne for vejledning på deres fag. I forlængelse af den konkrete optælling ser vi nærmere på vejledernes holdning, herunder hvorvidt det drejer sig om et bevidst fravalg af de studienævnsvedtagne tiltag.

\subsection{Felles retningslinjer generelt}

I forhold til spørgsmålet om hvorvidt der overordnet findes fælles retningslinjer for specialevejledningen på faget, dvs. for hvordan man faktisk vejleder, er der en vis konsensus mellem studieledere og vejledere, mens påfaldende mange af de studerende ikke kender til disse. Dette kan ses som et tegn på vejledernes manglende interesse for at anvende retningslinjer og regler i deres egen praksis, men det kan også være at de findes implicit i vejledningen. Det vi kan konstatere, er at de studerende ikke er blevet gjort bekendt med de generelle retningslinjer.

På de syv adspurgte fag svarer tre studieledere at der findes et vejledningsmateriale i form af en pjece eller et hæfte, to andre at man har indført specialeaftaler. De to sidste studieledere oplyser at man ikke har nogen konkrete fælles retningslinjer, idet de begge dog anfører at man har en konsensus eller en usus. Den ene mener at faget (fag 3) er så lille at det ikke er nødvendigt at indføre formelle, skriftlige regler. Studielederen henviser til muligheden for konsensus på lærermøderne, hvilket med fă ansatte er overskueligt ${ }^{4}$. De ikkeeksisterende regler bekræftes af alle seks vejledere på de to fag, men om der er konsensus om vejledning, må dog betvivles idet en af vejlederne på fag 3 (V8) fremhæver at han har sine egne retningslinjer og således ikke interesserer sig for om der er udarbejdet fælles retningslinjer. To af vejlederne på fag 3 er i tvivl om hvorvidt der faktisk findes retningslinjer. På fag 3 og fag 7 kan man trods dette ikke sige at der er manglende kendskab til retningslinjer, idet fagenes ledelse har det standpunkt at der ikke er behov for eksplicitte retningslinjer. Dette antyder at holdninger til retningslinjer kan være forbundet med en generel kultur på faget ${ }^{5}$. På de tre fag hvor der er en fælles pjece, kender syv ud af ni vejledere denne, en kender til eksistensen af en pjece, men gør opmærksom på at han ikke husker indholdet i detaljer, og en enkelt kender ikke noget til en sådan pjece. Af de i alt ni studerende på disse fag kender fem ikke til eksistensen af retningslinjer, mens tre fortæller at der er klare retningslinjer. På de to fag hvor der er indført specialeaftaler, kender de fem af vejlederne til aftalen, mens en enkelt fortæller at der i princippet er noget med en slags kontrakt. Denne vejleder fremhæver desuden at der vejledes meget forskelligt på faget. Ikke alle studerende er klar over at der er indført kontrakter. En af de studerende som har hørt om kontrakterne, har ikke sat sig ind i dem og kender ikke sin egen vejleders retningslinjer, men mener at det er noget man undersøger hvis man har problemer.

På spørgsmålet »Har I fælles retningslinjer for vejledningen? « svarer deltagerne i undersøgelsen følgende:

\begin{tabular}{|c|c|c|c|}
\hline Fag & $\begin{array}{l}\text { Studieledernes } \\
\text { oplysninger }\end{array}$ & Vejledere & Studerende \\
\hline I & $\begin{array}{l}\text { Ja. } \\
\text { (Har indført en } \\
\text { specialeaftale) }\end{array}$ & $\begin{array}{l}\text { VI Ja, kontrakt. Man kan få vejledning i hvad } \\
\text { der svarer til et halvt år. } \\
\text { V2 Nej. Meget forskellig praksis. I princippet } \\
\text { noget med en specialekontakt. } \\
\text { V3 Ja, forskellige papirer om tidsplaner og nu } \\
\text { også en slags kontrakt. }\end{array}$ & $\begin{array}{l}\text { SI Ja. Noget nyt, har ikke sat sig ind i det. } \\
\text { Uformelle kontrakter. Kender ikke egen } \\
\text { vejleders retningslinjer - noget man } \\
\text { undersøger hvis man har problemer. } \\
\text { S2 Kender ikke til fælles retningslinjer fra eget } \\
\text { forløb. Vejleder havde egne regler. Har hørt } \\
\text { om specialekontrakter som nyt tiltag. } \\
\text { S3 Tror der er regler, kender dem ikke. } \\
\text { Mener der er ved at blive udarbejdet } \\
\text { specialekontrakter. }\end{array}$ \\
\hline 2 & $\begin{array}{l}\text { Ja. } \\
\text { (Hæfte med } \\
\text { retningslinjer) }\end{array}$ & $\begin{array}{l}\text { V4 ja, en lille pjece. } \\
\text { V5 Ja, overordnede retningslinjer for hvor } \\
\text { meget man læser af specialet. } \\
\text { V6 Enighed om en række ting. Fx at undgå at } \\
\text { læse hele specialet. }\end{array}$ & $\begin{array}{l}\text { S4 Ja, vejleder gjorde dem helt klare fra starten } \\
\text { af. } \\
\text { S5 Kender ikke retningslinjer, har ikke } \\
\text { specialekontrakter. } \\
\text { S6 Ja, fik dem udleveret. }\end{array}$ \\
\hline 3 & Nej. & $\begin{array}{l}\text { V7 Nej } \\
\text { V8 Muligt at der foreligger retningslinjer, men } \\
\text { ikke trængt igennem. Har sin egen praksis. } \\
\text { V9 Har svært ved at komme i tanke om fælles } \\
\quad \text { retningslinjer. }\end{array}$ & $\begin{array}{l}\text { S7 Mener de findes, men kender dem ikke. } \\
\text { S8 Nej. } \\
\text { S9 Nej. Der står lidt i studieordningen. }\end{array}$ \\
\hline
\end{tabular}




\begin{tabular}{|l|l|l|l|}
\hline 4 & $\begin{array}{l}\text { Ja. } \\
\text { (Specialeaftaler) }\end{array}$ & $\begin{array}{l}\text { VI0 Ja. Specialekontrakter og tekst på } \\
\text { hjemmeside. } \\
\text { VII Ja. } \\
\text { VI2 Ja. I form af et regelsæt. }\end{array}$ & $\begin{array}{l}\text { SI0 Der er officielle regler. Der er } \\
\text { specialekontrakter. } \\
\text { SII Kender ikke til dem - tror der er kommet } \\
\text { klarere retningslinjer for nylig. } \\
\text { SI2 Ja. Fælles retningslinjer og en } \\
\text { specialekontrakt. }\end{array}$ \\
\hline 5 & $\begin{array}{l}\text { Ja. } \\
\text { (Specialepjece med } \\
\text { fokus på proces og } \\
\text { forventninger til } \\
\text { vejleder) }\end{array}$ & $\begin{array}{l}\text { VI3 Tror det ikke. } \\
\text { VI4 Ja - men få kender dem, kan ikke selv } \\
\text { huske dem i detaljer. } \\
\text { VI5 Ja. Studieordningen og specialepjece. }\end{array}$ & $\begin{array}{l}\text { SI3 Kender ikke til retningslinjer. } \\
\text { SI4 Kender ikke til reglerne. } \\
\text { SI5 Der er helt klare retningslinjer officielt. }\end{array}$ \\
\hline 6 & $\begin{array}{l}\text { Ja. } \\
\text { (Specialevejledning på } \\
\text { tryk og på nettet) }\end{array}$ & $\begin{array}{l}\text { VI6 Ja, pjece på nettet. } \\
\text { VI7a, der er en pjece.Vi snakker indbyrdes } \\
\text { om, hvordan vi gør. } \\
\text { VI8 Ja, ud over det der står i studieordningen, } \\
\text { har vi en vejledningspjece. }\end{array}$ & $\begin{array}{l}\text { SI6 Har fået at vide hvor meget de må læse, } \\
\text { men har glemt det. } \\
\text { SI7 Nej. } \\
\text { SI8 Ja, vejlederen gjorde regler klare fra } \\
\text { starten. }\end{array}$ \\
\hline 7 & $\begin{array}{l}\text { Nej. } \\
\text { (Men der er en } \\
\text { kultur, en usus) }\end{array}$ & $\begin{array}{l}\text { VI9 Nej, uformelle retningslinjer. } \\
\text { V20 Nej. } \\
\text { V2I Nej, ikke eksplicit. }\end{array}$ & $\begin{array}{l}\text { SI9 Tror det ikke. } \\
\text { S20 Kender ikke til regler. } \\
\text { S2I Ved det ikke. }\end{array}$ \\
\hline
\end{tabular}

Figur I: Retningslinjer for vejledning

På de fleste af de adspurgte fag har vejledning været diskuteret på studienævns- og medarbejdermøder, og der er flere steder blevet etableret aftaler om hvor meget man vejleder, eller hvor meget man læser inden aflevering eller lignende, men det bliver sjældent en viden som deles af alle, eller som overlever særlig længe:

»Vi har haft det oppe nogle gange. Det tenderer til, synes jeg, at når der er gået et stykke tid, så glemmer man hvad det egentlig var man aftalte, og det løber lidt ud i sandet, og så må man én gang til gribe det an." (V6)

At reglerne ikke altid er præsente hos alle, understreges af følgende vejlederudsagn:

"Jeg har en fornemmelse for at det er de færreste der egentlig kender dem. Jeg kan ikke selv huske dem i detaljer. Der findes noget om hvor mange gange de specialestuderende kan komme, og hvor meget man skal læse igennem, og hvor meget tid man skal bruge på det. Det er min fornemmelse at det er meget meget forskelligt hvordan det praktiseres rundt omkring." (V14)

Vi kan konstatere at selv om regler og retningslinjer - når de findes - ofte er udviklet $\mathrm{i}$ en form for medarbejderdemokrati, nemlig i studienævnet eller på medarbejdermøder, så bliver de ikke delt af alle og ikke husket af alle. De vejledere som har været med til at aftale dem, som V6 her ovenfor, fortæller at man med tiden glemmer hvad man aftalte. De øvrige medarbejdere føler sig tydeligvis ikke særlig berørte af denne type aftaler, sådan som det også fremgår af V14's udsagn. I denne forbindelse er sammenligningen med den centralt vedtagne e-mail-politik (Grønning 2006) relevant, og der synes ikke at være nævneværdig forskel på gennemslagskraften for en politik der er vedtaget af en fjern ledelse og en mere demokratisk vedtagen politik. Årsagen til den manglende gennemslagskraft skal således måske snarere søges i den måde regler og retningslinjer formidles på til praktikerne. Når det gælder specialevejledning, skal der uden tvivl meget til at ændre på en hævdvunden individuel praksis; en meddelelse om tidsmæessig normering, hvad enten den sendes ud til medarbejderen ${ }^{6}$ eller lægges på hjemmesiden, risikerer at få meget ringe betydning for den enkelte. Forandring af komplekse praksisser kan med fordel ske ved at man opsøger den konkrete praksis og tager afsæet i denne. Her er et felt som universitetspædagogikken skal være opmærksom på (in situ-princippet ${ }^{7}$.

\subsection{Tidsmossige normer for vejledning}

I forhold til de kvantitative mål for vejledning rammer mange vejledere forkert når de gætter på timetal for vejledning. I de tilfælde hvor vejlederne er bevidste om de konkrete retningslinjer, lader det under alle omstændigheder til at være klart at disse ikke anvendes ens. De studerende er kun i ganske få tilfælde klar over hvor mange timer der er afsat til vejledningen.

På spørgsmålet "hvor mange timer/gange vejledes der? svarer deltagerne følgende: 


\begin{tabular}{|c|c|c|c|}
\hline Fag & Fagets oplysninger 8 & Vejledere & Studerende \\
\hline I & 30 timer. & $\begin{array}{l}\text { VI Nej. } \\
\text { V2 I5, måske } 20 \text { timer. } \\
\text { V3 Er ikke bekendt med regler. Der findes en } \\
\text { fast norm. Gætter på } 40 \text { timer. }\end{array}$ & $\begin{array}{l}\text { S1 Kender ikke regler. } \\
\text { S2 Kender ikke regler. } \\
\text { S3 Kender ikke til regler. }\end{array}$ \\
\hline 2 & 50 timer. & $\begin{array}{l}\text { V4 Tror det er } 40 \text { timer i alt. } \\
\text { V5 En øvre grænse på } 50 \text { timer. } \\
\text { V6 Kan ikke huske hvor mange timer det er. }\end{array}$ & $\begin{array}{l}\text { S4 } 40 \text { timer til vejledning. } \\
\text { S5 Kender ikke til regler. } \\
\text { S6 Ved ikke præcist. }\end{array}$ \\
\hline 3 & 50 timer. & $\begin{array}{l}\text { V7 Ingen regler. } \\
\text { V8 Kender ikke til regler. } \\
\text { V9 Nej, det har vi ikke haft. }\end{array}$ & $\begin{array}{l}\text { S7 Det må der være, men kender dem ikke. } \\
\text { S8 Nej, ikke retningslinjer for selve } \\
\text { vejledningen. } \\
\text { S9 Nej, ikke i detaljer, men der står lidt i } \\
\text { studieordningen. }\end{array}$ \\
\hline 4 & $\begin{array}{l}50 \text { timer. } \\
\text { (Specialekontrakt } \\
\text { med } 8 \text { møder) }\end{array}$ & $\begin{array}{l}\text { VIO Nej. } \\
\text { VII } 6 \text { hovedmøder + } 2 \text { (indledende og } \\
\text { afsluttende). } \\
\text { VI2 6-7 samtaler over } 6 \text { måneder. }\end{array}$ & $\begin{array}{l}\text { SIO } 6 \text { gange. } \\
\text { SII Kender ikke til dem - tror, der er kommet } \\
\text { klarere retningslinjer efter hun havde } \\
\text { vejledning. } \\
\text { SI } 2 \text { Ikke besvaret - kun henvisning til kontrakt. }\end{array}$ \\
\hline 5 & 50 timer. & $\begin{array}{l}\text { VI3 } 50 \text { timer pr. speciale. Man har snakket om } \\
\text { max. } 5 \text { gange eller noget i den retning. } \\
\text { VI4 } 50 \text { timer. } \\
\text { VI5 } 45 \text { eller } 50 \text { timer. Passende gennemsnit. }\end{array}$ & $\begin{array}{l}\text { SI3 Kender ikke til retningslinjer. } \\
\text { SI4 Kender ikke til reglerne. Tror der er en } \\
\text { ramme, men ret frit. } \\
\text { SI5 } 60 \text { timer til vejledning. }\end{array}$ \\
\hline 6 & 50 timer. & $\begin{array}{l}\text { VI6 Nej, men vi har regler om timetal. Tror } \\
\text { det er } 40 \text { timer. } \\
\text { VI7 Det er registreret som en } 40 \text { timers } \\
\text { opgave. } \\
\text { VI8 } 40 \text { timer. }\end{array}$ & $\begin{array}{l}\text { S16 Kender ikke til regler. } \\
\text { SI7 Kender ikke til regler. } \\
\text { SI8 Vejlederen sagde fra starten af hvor mange } \\
\text { timer. }\end{array}$ \\
\hline 7 & 50 timer. & $\begin{array}{l}\text { V19 lkke fastsat. } \\
\text { V20 lkke fastsat. } \\
\text { V2I } 20 \text { - } 30 \text { timer. Meget stor forskel på hvor } \\
\text { meget tid man bruger på de studerende. }\end{array}$ & $\begin{array}{l}\text { S2I Ved ikke. } \\
\text { S20 Har læst et sted at vejlederen fă løn for } \\
\text { I0 timer, men det er ikke noget han har } \\
\text { sagt. } \\
\text { S19 Kender ikke til regler. }\end{array}$ \\
\hline
\end{tabular}

Figur 2: Antal timer/gange til vejledning

Der er stor uklarhed omkring normerne for vejledning, og der er ikke nogen klar bevidsthed om hvorvidt man refererer til fakultetets norm eller til en lokalt vedtaget norm, ej heller om normen omfatter bedømmelse. Fakultetsnormen var på interviewtidspunktet 50 timer på Humaniora og 30 timer på Teologi. Dette er studielederne bevidste om, mens vejlederne enten ikke er bekendte med fælles normer, ikke går op i eller ikke kan huske disse og i øvrigt gætter mere eller mindre ved siden af. De studerende er slet ikke klar over hvor mange timer der er afsat til vejledning og bedømmelse. På et enkelt af de adspurgte fag (fag 4) er timetallet målt op i en kontrakt med 8 møder af omkring en time, og dette er mere eller mindre tydeligt for vejlederne og de studerende. Det er påfaldende at der er nogle fag hvor bevidstheden om timetal for vejledning er langt større end på andre, fx fag 3 og 6. Dette indikerer endnu en gang at tendenserne er udtryk for en kultur på det enkelte fag. En kultur som generelt ikke opfatter specialevejledning som en fælles ensartet praksis.

Vi kan samlet set konstatere at der ikke er stor klarhed om de kvantitative rammer for vejledning hos en del medarbejdere - som tydeligvis heller ikke finder det særlig vigtigt $i$ forhold til deres egen vejledningspraksis. Ud af 21 vejledere kender fem til normeringen, en er usikker, og 15 ved ikke hvor mange timer ${ }^{9}$ denne opgave tæller hos deres studieledelse og dermed hos deres arbejdsgiver. Det er umiddelbart overraskende at arbejdstidsnormer ikke synes at være interessante for så stor en del af vejlederne. Dette understøttes af følgende udsagn fra vejledere:

»I arbejdstidskompensation er der en fast norm som jeg ikke lige her kan nævne.» (V3)

"Altså, der er et bestemt antal timer i vores timeregnskab, jeg kan ikke huske hvor mange det er [...] Det siger også noget om hvor lidt jeg interesserer mig for det." (V6)

»Jeg tror vi får timer på vores kapacitetsskema, og det er en 30 timer eller sådan en 20-30 timer. Men det ved studielederen præcist. Men der er meget stor forskel.»(V21) 
Når det gælder specialevejledning, går vejlederne ikke op i hvor megen tid de bruger. Når vi spørger til det, er der stor vilje til at besvare spørgsmålet, men ikke nogen personlig interesse $\mathrm{i}$ det. I undersøgelsen som helhed, med inddragelse af kvalitative udsagn om vejledningens indhold og de studerendes forskellighed, kan vi konstatere at en tidsmæssig opmåling af vejledningen ikke synes relevant, og at vejlederne derfor ser dette som studielederens område, hvilket også direkte fremgår afV21's udsagn.

\subsection{Antal loste sider af specialet}

Det tredje spørgsmål om fælles retningslinjer for vejledning handler om hvor stor en del af et speciale de studerende kan forvente, vejlederne vil læse. Også på dette område er der stor divergens mellem studieledernes forestilling om den fælles konsensus, vejledernes idé om praksis og de studerendes bevidsthed om samme.

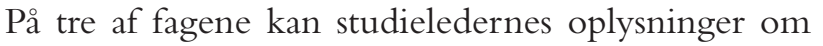

at der læses henholdsvis 10-25\%, $40 \%$ og 50\% af et speciale, ikke genfindes hos vejlederne eller hos de studerende. På fag 1 mener to vejledere at det ligger omkring en tredjedel af et speciale, mens den sidste vejleder og to af de studerende ikke er bekendt med regler eller ikke mener at der findes sådanne. En enkelt studerende oplyser at vejlederens retningslinjer er $10 \%$. Både på fag 5 og 6 er der en enkelt vejleder hvis norm er sammenfaldende med studielederens, mens de to øvrige vejledere ikke mener der er retningslinjer. De tre adspurgte studerende på fag 6 husker ikke antallet af sider, mens de to studerende på fag 5 der har besvaret spørgsmålet, ikke kender til retningslinjer. På to fag (fag 2 og 4) er der konsensus hele vejen fra studieleder til studerende om at der læses $25 \%$ af det færdige speciale, mens der på fag 1 og 3 er en næsten klar konsensus om at der ingen regler er ${ }^{10}$.Vi kan altså her ganske tydeligt konstatere at der på fagene findes forskellige kulturer for såvel regelsætning som videndeling.

\begin{tabular}{|c|c|c|c|}
\hline Fag & $\begin{array}{l}\text { Studieledernes } \\
\text { oplysninger }\end{array}$ & Vejledere & Studerende \\
\hline I & $\begin{array}{l}\text { Ingen regler. } \\
\text { Det er meget } \\
\text { forskelligt. Ingen } \\
\text { fandt behov for fælles } \\
\text { retningslinjer. }\end{array}$ & $\begin{array}{l}\text { VI Et kapitel eller hvad der svarer til } 20-25 \\
\text { sider + alle dispositioner og synopser.Ved } \\
\text { ikke om det er nedskrevet. } \\
\text { V2 Der er retningslinjer fra studielederens } \\
\text { side, men har dem ikke helt præsent. } \\
\text { V3 Det er meget forskelligt. }\end{array}$ & $\begin{array}{l}\text { SI Kender ikke til regler. } \\
\text { S2 Kender ikke til regler. } \\
\text { S3 Tror det er en femtedel af specialet. }\end{array}$ \\
\hline 2 & $\begin{array}{l}\text { Tommelfingerregel: } \\
25 \% \text {. } \\
\text { Stor forskel } \\
\text { indbyrdes. }\end{array}$ & $\begin{array}{l}\text { V4 Ca. } 20 \% \\
\text { V5 Tror det er } 25 \% \\
\text { V6 Op til den enkelte: en mindre del af } \\
\text { specialet. }\end{array}$ & $\begin{array}{l}\text { S4 } 20-25 \% . \\
\text { S5 Mener det er halvdelen. } \\
\text { S6 Mener det er ca. } 20 \text { sider. }\end{array}$ \\
\hline 3 & $\begin{array}{l}\text { Ikke skriftlige } \\
\text { retningslinjer, men } \\
\text { klar konsensus. } \\
\text { Som regel ret store } \\
\text { dele af specialet. } \\
\text { I enkelte tilfælde } \\
\text { næsten det hele. }\end{array}$ & $\begin{array}{l}\text { V7 Nej. } \\
\text { V8 Nej. } \\
\text { V9 Nej. }\end{array}$ & $\begin{array}{l}\text { S7 Kender ikke til regler. } \\
\text { S8 Nej. } \\
\text { S9 Nej - nogle taler kun med deres vejleder } \\
\text { om emnet i starten, andre har fået hele } \\
\text { deres speciale gennemlæst. }\end{array}$ \\
\hline 4 & $25 \%$ & $\begin{array}{l}\text { VIO } 25 \% \\
\text { VII ca. } 20-25 \% \\
\text { VI2 } 25 \% \text {, ca. } 20 \text { sider. }\end{array}$ & $\begin{array}{l}\text { SIO I5-20\%. } \\
\text { SII Ved det godt, vejlederen overholdt det. } \\
\text { Svarer ikke på hvor mange sider det var. } \\
\text { SI } 2 \text { Ca. } 25 \% \text {. }\end{array}$ \\
\hline 5 & $50 \%$ & $\begin{array}{l}\text { VI3 Det første kapitel eller de første } 20 \text { sider. } \\
\text { VI4 } 25 \text { sider, altså ca. en fjerdedel af specialet. } \\
\text { Men jeg kan ikke huske det. } \\
\text { VI5 Ca. } 50 \% \text {. }\end{array}$ & $\begin{array}{l}\text { SI } 3 \text { Kender ikke til retningslinjer. } \\
\text { SI } 4 \text { Ved ikke. } \\
\text { SI } 5 \text { Er ikke besvaret. }\end{array}$ \\
\hline 6 & $40 \%$ & $\begin{array}{l}\text { VI6 Der er ikke fælles retningslinjer. } \\
\text { VI7 Ikke fælles retningslinjer. } \\
\text { VI8 Ca. } 40 \% \text {. Måske halvdelen, ikke over. }\end{array}$ & $\begin{array}{l}\text { SI6 Har fået det at vide, men har glemt det. } \\
\text { SI7 Der må læses en bestemt procentdel. } \\
\text { SI8 Vejlederen sagde fra starten af hvor meget } \\
\text { hun måtte læse. }\end{array}$ \\
\hline 7 & $10-25 \%$ & $\begin{array}{l}\text { V19 Det er der ikke regler for. } \\
\text { V20 } 30 \text { sider } / 30 \% \\
\text { V2I Ca. en tredjedel. }\end{array}$ & $\begin{array}{l}\text { S19 Ved ikke. } \\
\text { S20 Vejlederens egne retningslinjer er } 10 \% \text {. } \\
\text { S2I Kender ikke til regler. }\end{array}$ \\
\hline
\end{tabular}

Figur 3: Antal læste sider af et speciale 
Sammenfattende kan vi konstatere at mange vejledere enten er på et fag hvor der ikke er regler (fag 5 og 7) eller ikke kender dem. På de fem fag hvor der er regler for hvor meget der læses, kender seks ud af $\mathrm{i}$ alt 15 vejledere disse regler, fire rammer tæt på normen i deres gæt, og fem kender den ikke eller gætter helt ved siden af. Det vil sige at 11 ud af 21 vejledere ikke har eller kender til regler for hvor meget der læses af et speciale. Blandt de studerende kender 10 ikke til regler (en dog fordi hun har glemt det), mens 10 andre gør ${ }^{11}$, enten for faget eller for deres egen vejleder. Manglende regelsætning på dette område er problematisk for de studerendes retssikkerhed. En af de studerende på fag 5 (S15) gør da også opmærksom på at dette medfører meget forskellige vilkår for de specialestuderende.

\section{Vejledernes syn på egen rolle}

Når man på tværs af de tre spørgsmål undersøger hvor mange gange vejlederne ikke kan huske de specifikke regler eller svarer forkert når de gætter på disses udformning, fremgår det at der er tale om ca. en fjerdedel forkerte svar. I betragtning af at der er tale om ganske simple spørgsmål der angår et arbejdsområde for deltagerne, mener vi der er tale om en udbredt mangel på kendskab, hvilket især manifesterer sig på nogle af de adspurgte fag.Vi kan på baggrund af foregående afsnit konstatere at nogle vejledere i ret høj grad ikke kender til deres fags eventuelle overordnede retningslinjer og regler for specialevejledning. Retningslinjerne når $\mathrm{i}$ endnu mindre grad frem til de studerende, idet meget få kunne svare på spørgsmål om gældende retningslinjer, hvilket kunne tyde på at vejlederne i ringe grad tematiserer de formelle - eller indholdsorienterede retningslinjer i selve vejledningen.Vejlederne har deres egen praksis som de ikke så let ændrer på. Det skal i den forbindelse nævnes at en stor del af vejlederne $i$ undersøgelsen uopfordret fremhæver at vejledning er en kerneaktivitet $\mathrm{i}$ deres arbejde som de lægger stor vægt på at sætte tid af til. Et væsentligt element i god vejledning er i vejledernes øjne at de har en god praksis, og at de er meget fleksible og tilpasser vejledningen til den enkelte:

"Det er igen noget individuelt. Med nogle studerende planlægger vi flere møder frem. Andre - der tager vi det meget ad hoc hvor vi altid er enige om at de kontakter mig snart." (V10)

Det kan logisk føre til en meget lille interesse for fælles retningslinjer eller direkte til en stillingtagen imod sådanne, sådan som vi har set på fag 7 :

"På den anden side så er de studerende og situationen så varierede og så forskellige, og det er derfor vi ikke har følt os foranledigede til at have faste regler for det« (SL7)
Flere vejledere påskønner dog retningslinjer, også selv om de anskuer vejledning som noget individuelt:

"Altså, hvad er et godt vejledningsforløb? Hvilke ting skal man tage højde for, og hvordan kan man strukturere sådan et vejledningsforløb? Så der er i hvert fald nogle fælles retningslinjer at forholde sig til. Og det er jo altså alt lige fra hvordan finder man ud af at finde sig en vejleder, til et spørgsmål om hvordan man skriver sit speciale. Forstået på den måde at hvad er det for formelle krav der skal opfyldes. Så der ligger en vejledning som det er mit indtryk, bruges. Og jeg bruger den i hvert fald selv når jeg starter en vejledning. Så henviser jeg, hvis den studerende ikke kender den, til vores website hvor den findes. Så de har læst den igennem."(V18)

Endelig er der en gruppe (fortrinsvis yngre) vejledere ${ }^{12}$ som efterspørger retningslinjer, og som finder at det er en unødig arbejdsbelastning for den enkelte vejleder selv at skulle finde frem til sine egne. En vejleder har selv udarbejdet skriftlige retningslinjer for vejledningen som han udleverer til sine specialestuderende:

"Jeg har de her retningslinjer som jeg giver dem. Jeg skrev nogle af de ting ned som jeg vidste jeg gjorde hele tiden, og så gik jeg på nettet og kiggede på nogle af de amerikanske universiteter, og jeg skaffede nogle bøger om hvordan man skriver speciale, og det er hvad jeg baserede det på.« (V10)

En anden yngre vejleder er i færd med at udarbejde sine egne retningslinjer, bl.a. som et led i kvalitetsudviklingen af sin egen vejledning, med henblik på feedback fra kolleger:

"Jeg har selv skrevet et dokument nu som jeg er begyndt at cirkulere blandt de studerende jeg har og også andre kolleger, og sagt "gider I give mig feedback?« Så jeg har sådan set gået omvendt ud og sagt: 'Efter at jeg har vejledt i et par år, hvordan kan jeg så se at min rolle er?" "(V11)

Dette sidste eksempel, hvor en vejleder helt konkret deler sine erfaringer og retningslinjer med sine kolleger med henblik på feedback og fælles kvalitetsudvikling, er dog en undtagelse i forhold til undersøgelsens generelle resultat.Vejlederne oparbejder en stor individuelt baseret erfaring og en egen praksis, hvilket vi fortolker som demotiverende for dem $\mathrm{i}$ forhold til at gå ind i nye måder at vejlede på og $\mathrm{i}$ forhold til at bakke op om centrale eller 'ovenfra' kommende initiativer til systematisering af vejledningen. 


\section{Læringsteoretiske og historiske perspektiver for vejlederens rolle}

Set i et læringsteoretisk perspektiv er det logisk at man ikke uproblematisk påvirker en gruppe som man har ladet udvikle sin egen - ofte velfungerende - praksis og metode uforstyrret i for manges vedkommende over en lang årrække. Det er et stort skridt at skulle åbne sig for forandring når man opfatter sig selv som kompetent på et område (jf. Illeris, "Hvad er det særlige ved voksnes læring?", Carsten Nejst Jensen (red.): Voksnes locingsrum, 2005) og har en stabil oplevelse af sin egen arbejdsmæssige identitet (jf. Erikson, Identitet - ungdom og kriser, 1971). Når disse initiativer dertil kommer fra et niveau som vejlederen ikke er vant til at samarbejde med i pædagogiske spørgsmål, hvad enten det er studieledelsen eller fakultetsniveauet, vil reaktionen - som vi da også kan konstatere - ofte være at man ignorerer eller glemmer dem. Mange vejledere i undersøgelsen har vejledt mellem 20 og 200 specialer, og de vil ikke være tilbøjelige til at ændre grundlæggende på deres praksis. De har oparbejdet en praksis der fungerer, og så er det svært at være åben for at lave noget om (jf. Illeris 1999, Liveng 2004). De yngre vejledere viser sig imidlertid at være meget interesserede $\mathrm{i}$ at diskutere deres praksis med kolleger og studerende. Der er en generel tendens til at både ph.d.-studerende og adjunkter når de præsenteres for nye opgaver, forventer at blive klædt på til at klare dem ${ }^{13}$.

Det er en mangeårig kultur på universiteterne der har skabt denne stærkt individuelt orienterede praksis hvor argumentet om såvel vejledernes som de studerendes indbyrdes forskellighed opretholdes og helt uimodsagt bruges som begrundelse for ikke at lave fælles retningslinjer eller for fra studieledelsernes side ikke at forpligte nogen til at følge sådanne.

Masseuniversitetet - og nutidens unge - har imidlertid nødvendiggjort at man arbejder med eksplicitte rammer og mål for undervisning og vejledning. Moderne studerende udtrykker i mange sammenhænge behov for at få klargjort rammer og retningslinjer (præcis som de yngre vejledere). Universitetets bevægelse fra langtrukne, tålmodige studier til afgrænsede, målrettede uddannelser kræver at specialeprocessen bliver mere strømlinet, ligesom efterspørgslen på arbejdskraft i samfundet også spiller en rolle. I denne forbindelse er det en blokering for udvikling af vejledningstilbuddet når nogle vejledere udelukkende er forankret i en egen praksis der fungerer på en måde de ikke har lyst til at anfægte. Den privatpraktiserende kultur forhindrer forståelse for behovet for udvikling af vejledningen. Vi kan konstatere at flere yngre vejledere ser styrken i en fælles tilgang og vejledningskultur samt den potentielle aflastning der ligger $i$ fastere rammer og retningslinjer. Flere af de ældre vejledere påskønner nye tiltag, men fremhæver at det primært er for de andres skyld, fordi de selv har en velfungerende praksis.

\section{Konklusion}

Vi har undersøgt vejledernes kendskab og holdning til fælles rammer og retningslinjer for vejledning, både som kvalitetssikring (sikring af en fælles standard) og som kvalitetsudvikling (nye tiltag til bedre vejledning). Vi har i denne artikel taget udgangspunkt i besvarelser af tre spørgsmål vedrørende både sikring af en ensartet standard og forbedring af kvaliteten, med fokus på om eventuelle tiltag når ud til den enkelte vejleder og den enkelte specialestuderende. Således viser undersøgelsen et eksempel på hvordan rammesætning af undervisning og vejledning modtages i den kultur den skal fungere i. Parallellen til viden om e-mail-politik (Grønning 2006) eller centralt formulerede værdier og visioner i organisationer peger på at det generelt kan være svært at implementere fælles politikker i organisationer. Universitetslærere er ikke de eneste som fungerer som selvlærte i organisationer. Praksisviden udvikles af praktikere og rammesætning ofte af ledere. På universitetet har man en generel opfattelse af medarbejderne som autonome aktører, hvilket også har været grundopfattelsen i skoleverdenen og ungdomsuddannelserne hvor dette princip med de nye reformer i disse år i høj grad udfordres. Idealer som forskningsfrihed og metodefrihed er væentlige grundvilkår, men de bør ikke føre til privatisering af offentlige ydelser som undervisning og uddannelse. Det kan de studerende ikke være tjent med. Det kan vejlederne heller ikke være tjent med. Vejledning er ikke kun den enkeltes ansvar, men institutionens. Derfor er åbenhed over for fælles retningslinjer vigtig. Vi har påvist en mangel på interesse over for de fælles tiltag og rammer hos visse vejledere, men ikke hos alle. En vigtig modstand mod regelsætning vi har peget på, er at vejlederne ikke føler sig udfordret af disse ydre tiltag. Mange føler ikke at de kvantitative regler er på niveau med det produkt vejledningen udgør.Vi vil konkludere at hvis man ønsker at fă vejlederne i tale, skal der ikke blot tales om timer og sider, men om den enkelte vejleders erfaringer med indholdet $i$ vejledningen.

\section{Referencer}

Andersen, Hanne Leth \& Tine W. Jensen, under udg.: Specialevejledning - rammer og roller, Frederiksberg, Forlaget Samfundslitteratur.

Andersen, Hanne Leth \& Louise Søndergaard, under udg.: Kollegial supervision på universitetet, Aarhus Universitetsforlag.

Erikson, Erik H., 1971: Identitet - ungdom og kriser, København: Reitzel.

Grønning, Anette, 2006: Personen bag. Tilstedevar i e-mail som interaktionsform mellem kunde og medarbejder i dansk forsikringskontekst, Frederiksberg, Forlaget Samfundslitteratur.

Illeris, Knud, 2005: "Hvad er det særlige ved voksnes læring?«, Carsten Nejst Jensen (red.): Voksnes laringsrum, Værløse: Billesø og Baltzer, 50-63.

Illeris, Knud, 1999: Laring - aktuel laringsteori i spandingsfeltet mellem Piaget, Freud og Marx. København: Roskilde Universitetsforlag.

Kvalitet $i$ undervisningen (2005), rapport fra Forskningsministeriet 
Laursen, Per Fibæk, 2004: Den autentiske larer, Gyldendals lærerbibliotek.

Liveng,Anne, 2004: „Livshistorie som indgang til at forstå samspillet mellem uddannelse og arbejde", Pernille Bottrup \& Christian Helms Jørgensen (red.): Laring $i$ et spandingsfelt - mellem uddannelse og arbejde. Learning Lab Denmark, 117 - 131.

Rienecker, Lotte \& Thomas Harboe \& Peter Stray Jørgensen (2005) Vejledning - en brugsbog for opgave- og specialevejledere på videregående uddannelser, Frederiksberg, Forlaget Samfundslitteratur.

\section{Noter}

1 På undersøgelsestidspunktet, inden sammenlægningen af en række studienævn pr. 1. februar 2007, var studienævn og fag stadig nogenlunde sammenfaldende på Det Humanistiske Fakultet ved Aarhus Universitet. Regelsætningen var alene studienævnenes ansvar, bortset fra en fælles tidsnormering. Fremover vil regelsætningen kunne centraliseres, idet studienævnene sammenlægges så der kun er et studienævn pr. institut og studielederne alle er medlemmer af fakultetets uddannelsesudvalg. Disse udviklinger kan iagttages helt parallelt på andre fakulteter og universiteter.
5 Denne holdning kan være generel for et fag eller et institut, hvilket afhænger af hvordan kulturen har været bygget op. Vores undersøgelse tager udgangspunkt i studienævn og fag, og vi kan derfor ikke udtale os for hele institutter.

6 Ofte skal beslutninger af denne art dog findes i studienævnsreferater, som erfaringsmæssigt ikke nødvendigvis læses af alle undervisere.

7 Jf.Andersen, Hanne Leth og Louise Søndergaard (red.) under udg.: Kollegial supervision på universitetet, Aarhus Universitetsforlag.

8 Der fandtes på undersøgelsestidspunktet en fælles tidsnormering på fakultetsniveau, nemlig 50 timer inkl. bedømmelse. (Det er pr. 1/9 2006 ændret til 40 timer.) Samtidig havde en del af fagene deres egne normer, som studielederne refererer til. Spørgsmålet lagde ikke op til en differentiering af de to niveauer.

9 På et af fagene refererer vejlederne til en relativt nyindført specialekontrakts fastsættelse af antal mødegange. Vi vælger at betragte dette som en form for normering af arbejdstiden og kan konstatere at to ud af de tre adspurgte vejledere kender denne normering.

10 På fag 1 har både en af vejlederne og en af de studerende alligevel et klart billede af en fælles norm, hvilket måske stammer fra en tidligere fælles, nu glemt beslutning? Jf. afsnit $3.1 \mathrm{om}$ problemet med information om og implementering af såvel studienævnsbeslutninger som beslutninger taget på medarbejdermøder.

11 En enkelt studerende (S8) har ikke besvaret dette spørgsmål, og en anden (S17) nævner en norm der ikke gælder for hendes fag, hvilket indikerer at vejlederen i det konkrete tilfælde har afvigende regler i forhold til faget.

12 I alt drejer det sig om fem vejledere, alle under 45 år, der eksplicit efterspørger retningslinjer.

13 Det er en konkret erfaring fra vores arbejde på Center for Undervisningsudvikling at disse medarbejdergrupper efterspørger kurser når de præsenteres for nye opgaver. 